\title{
Microgram per Gram per Hour
}

National Cancer Institute

\section{Source}

National Cancer Institute. Microgram per Gram per Hour. NCI Thesaurus. Code C74922.

A dose calculation unit expressed in microgram(s) per gram per period of time equal to sixty minutes. 